\title{
Electronic Communication in Private Doctors' Surgeries in the Czech Republic
}

\author{
Veronika Novotná and Viktor Ondrák \\ Brno University of Technology \\ Faculty of Business and Management, Department of Informatics \\ Kolejní, Brno, Czech Republic \\ Correspondence should be addressed to: Veronika Novotná; novotna@fbm.vutbr.cz \\ Received date: 4 September 2014; Accepted date: 2 April 2015; Published date: 11 February 2016 \\ Academic Editor: Mihai Carp \\ Copyright (C) 2016. Veronika Novotná and Viktor Ondrák. Distributed under Creative Commons \\ CC-BY 4.0
}

\begin{abstract}
Doctors' surgeries are facing increasing demands on the time required for sending out reports, referrals and diagnoses of various kinds. This leads to a shortage of the time needed for the most important thing - patient care. The development of information technology and its increased use means ever-increasing possibilities for its use in simplifying the administrative work facing doctors' surgeries. Many doctors, however, are still not taking as much advantage of such software as they might. The aim of this paper is to determine how much interest there is in this simple and effective form of communication in private doctors' surgeries in the Czech Republic, to determine the level of use of electronic communication in dependence on doctors' areas of speciality, and to summarise the demands on information security laid down by the law. The exploratory analysis and multivariate statistical analysis method has been used for a deeper analysis of the data.
\end{abstract}

Keywords: eHealth, information technologies, cluster analysis

\section{Introduction}

Healthcare is one of the most widely discussed topics in the Czech Republic. There are many things in this area that could be improved, one of which is the method of communication between the doctor and the outside world (colleagues, patients, laboratories, etc.). Software enabling communication of this kind is already available to doctors, though many doctors still do not take the kind of advantage of this software that they might.The aim of this paper is to map out the current situation in regard to electronization in private doctors' surgeries in the Czech Republic and to determine the level of use of electronic communication as one means of e-Health currently available. Particular attention is devoted to an analysis of the behaviour of individual "groups" of doctors.Data available from the Czech Statistical Office (www.czso.cz) and the results of a questionnaire survey conducted at the beginning of 2013 have been used for this purpose. A questionnaire with twenty questions, of which some served for the verification of input data and the elimination of random answers, was drawn up for the purposes of this investigation. Four hundred

Cite this Article as: Veronika Novotná and Viktor Ondrák (2016)," Electronic Communication in Private Doctors' Surgeries in the Czech Republic ", Journal of Eastern Europe Research in Business and Economics, Vol. 2016 (2016), Article ID 398531, DOI: 10.5171/2015.398531 
doctors engaged in private medical practice in the Czech Republic were addressed within the given research. Three hundred and seventy-three completed questionnaires were returned, of which twelve were discarded as incomplete before further processing.

\section{eHealth}

The European Commission defines electronic healthcare IT (eHealth) as a "series of instruments based on information and communication technologies supporting and improving prevention, diagnostics, therapy, monitoring and maintenance of health and lifestyle"(European Commission, 2011).

Provision of high-standard healthcare according to Zvara et al. (2008) requires, inter alia, availability of relevant patient information, access to information for example about correct procedures including information about symptoms and diagnoses. Strategic planning of many healthcare organisations therefore includes planning of deployment and use of most up-to-date technologies for improvement of healthcare and reduction of operation costs (Goldschmidt P.G. 2005, Davidson, E \& all. 2006, Klein R. 2007). Various healthcare organisations provide various services to different economic categories and levels of diseases. Technological and research progress allows for more and more accurate diagnosing and applications of new and more effective therapeutic technologies (Singh H. \& all. 2008). As a consequence, current medical care is becoming more and more complex and expensive. (Douglas, T.J. \& Ryman J.A. 2003) All that is closely related to increased demand for healthcare contrasting to lack of qualified healthcare professionals, doctors and nurses. This very conflict is one of the biggest issues faced by healthcare providers (Young H.M. 2003, Healthcast 2006). Healthcare facilities are interested in information technologies facilitating logistic planning, patient management, laboratory result communication, sending of electronic messages between radiology, pharmacy and carer departments and hospitals and other healthcare facilities and general communication between them. (Iakowidis I. \& all. 2004)

Deployment and use of eHealth technologies becomes a general priority for its result which is improved healthcare provision (Thompson T.G. \& Brailer D.J. 2004, Overhage J.M. \& all. 2005). In the U.S.A. this effort leads to the receiving and use of electronic medical records as a means of data sharing facilitation, health information protection, privacy protection, safety and identification of potential threats to public health (Thompson T.G. \& Brailer D.J. 2004, Overhage J.M. \& all. 2005). Application of eHealth may also support clinical decisions and minimise the risk of human error caused by inaccuracy or incompleteness of paper documents (Thompson and Brailer 2004, Kawamoto et al. 2005, Ohsfeldt et al. 2005).

Nevertheless, the effects of utilisation of eHealth technologies need not by themselves mean improvement of healthcare itself (Linder J.A. \& all. 2007). All largely depends on the standards of the whole system and impact of its use in healthcare by individuals. In addition to material background, the successful practical launch of the eHealth system is further conditioned by the willingness and skills of healthcare professionals using it. Recent acknowledgement of the fact that new methods and techniques need to be accepted and adopted supports positive approach of healthcare personnel to the new technologies (Karsh B. 2004, Ash J.S. \& Bates D.W. 2005, Berner E.S. \& all. 2005). Without complex understanding of the experience of the end user, it is not possible to propose and implement eHealth technologies. It is the very human factor and organisational issues that partly explain why most private medical surgeries use eHealth options much less than they could and should (Middleton B. \& all. 2005, Jha A.K. \& all. 2006).

\section{e-Health and information security in the Czech Republic}

One of the greatest problems in the electronization of healthcare is the observation of information security in the areas of data storage, backup and, perhaps 
most importantly, electronic communication.

Keeping medical documentation exclusively in electronic form is allowed in the Czech Republic, under the condition that it contains a guaranteed electronic signature, in accordance with the wording of Act 227/2000 Sb. on Electronic Signatures and the Amendment of Certain Other Laws, but private doctors in particular take practically no advantage of this possibility. The main reason they give for this are their concerns relating either to interrupted accessibility or to the integrity of the data stored, i.e. the possible loss or degradation of stored information on patients which could have existential consequences for them. They consider backing up on mobile or remote media, on the other hand, to be risky in view of data confidentiality as any leak of sensitive personal data could result in significant penalties in accordance with Act 101/2000 Sb. on the Protection of Personal Details.

Act $181 / 2014$ Sb. on Cybernetic Security and the Amendment of Related Laws comes into effect in the Czech Republic on 1 January 2015. This law imposes obligations on the administrators of the information systems of critical infrastructure and the administrators of important information systems, and these undoubtedly include medical information systems. Large information systems (communication with health insurance companies, the keeping of medical documentation, e-Prescriptions, etc.) can be expected to be modified by their creators in the near future in order to comply with this law and supplement with methodical instructions for their operation.

What cannot be expected in the immediate future, however, is the methodical modification of information security in the area of informal communication between doctors and other medical institutions and between doctor and patient. This communication is generally conducted over the telephone, by SMS, e-mail or fax, or with the use of proprietary information systems, although the use of social networks, i.e. extremely vulnerable media, is also seen in some cases.

\section{Communication between practitioners and their social context}

The data which enable analysing the attitude of Czech practitioners towards electronic communication have been taken from databases of the Czech Statistical Office (www.czso.cz). It is mainly information concerning practitioners' electronic communication with pharmacies, business partners, health-care facilities, health insurance companies and, above all, with patients and wide public.

It is necessary for the general population to use the Internet and to be computer and Internet literate in order for it to be possible to take advantage of the possibilities of eHealth. The largest group in this case is made up of patients, though they are not faced with the kind of demands that are placed on doctors. Data are produced in doctors' surgeries that doctors have to process, and they must then be capable of interpreting the results and applying them in practice.

The data that allow an analysis of the behaviour of doctors in the Czech Republic in relation to electronic communication with the outside world have been obtained primarily from the database of the Czech Statistical Office (www.czso.cz). This information shows whether doctors communicate electronically with pharmacies, business partners, medical institutions, health insurance companies and, of course, with patients and the public.

Interviews with doctors themselves have shown that it is their patients who are important partners for communication. This fact raised the question as to what forms of electronic communication they prioritise in communicating with their patients. Until recently, the most widely used form of remote doctor-patient communication was based on the use of the telephone. Appointments were also made in this way. Consultation over the telephone, however, does not generally make it possible to give a detailed and accurate description of the given problem in view of the accompanying stress felt by the patient or the doctor. A written form of communication is often more suitable for this purpose. 
As this information is not available from the above source, the results of a piece of research undertaken in the Czech Republic at the beginning of 2013 were used. As has been stated in the introduction to this paper, we addressed four hundred doctors within the framework of this research, of which three hundred and seventy-three completed our questionnaire. The answers they gave to questions relating to communication with other doctors and laboratories and forms of electronic communication with patients (email, SMS, on-line consultation) were relevant to our paper.
We studied the behaviour of five groups of doctors for the purpose of our analysis:

Adult general practitioners

- Paediatricians

- Gynaecologists

- Dentists

- Specialist doctors

Data for the statistical analysis of e-Health in the Czech Republic were taken from the data shown in the graph, Figures 1 and 2, in which values are given in percent. These values show what percentage of doctors in the individual groups use the given means of communication.

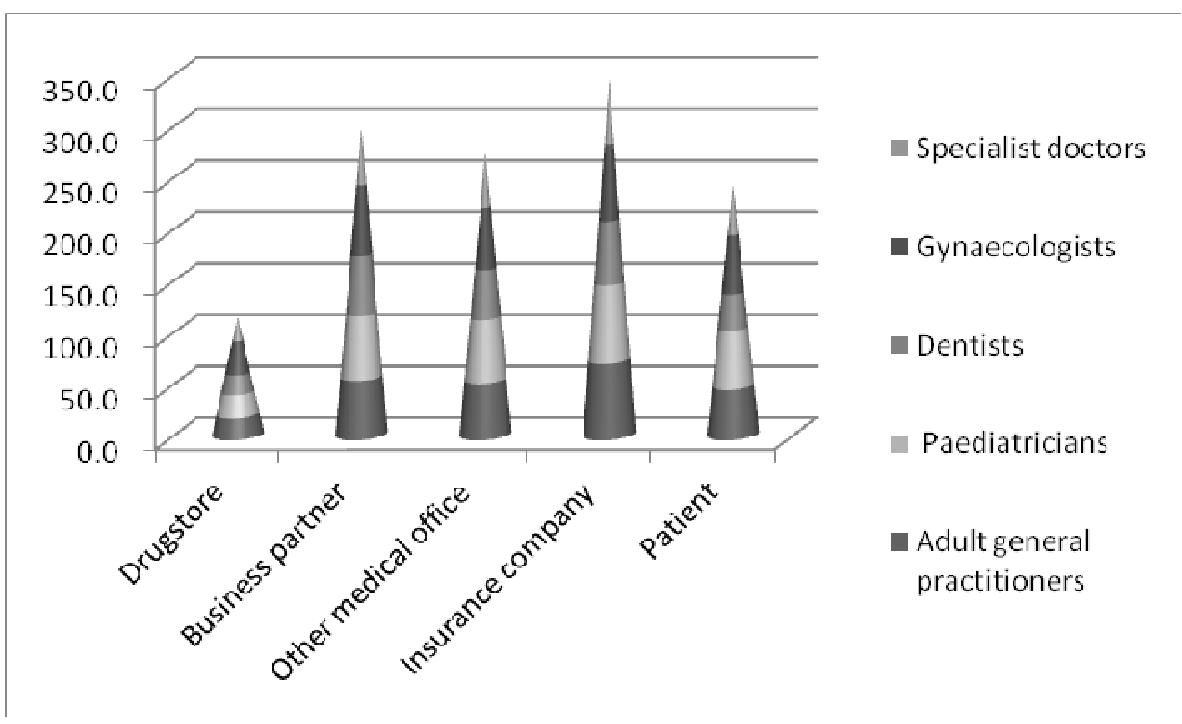

Figure 1: Certain way of e-communication (Source: own)

It is clear from Figure 1 that electronic communication is used most with health insurance companies. The reason for this is evidently the fact that medical institutions, having a contract closed with a health insurance company, generally perform the settlement of healthcare provided monthly or quarterly. The frequency of settlement is given in the contract between the medical institution and the health insurance company. The reason for the interest seen in electronic communication with health insurance companies is the possibility of achieving a significant reduction in administrative work, simplifying and speeding up the entire process, and perhaps earlier payment for care provided. The use of electronic communication also means that the settlement of accounts can be checked on line which gives doctors immediate feedback as to whether payments have been prepared properly. The doctor also does not have the same concerns about the violation of information security when communicating with health insurance companies - on one hand the system of communication is administered by the health insurance company which bears full responsibility for the information security of its systems, while on the other hand such 
communication does not contain such a quantity of sensitive personalised data.

Information technology is being used to an ever-increasing extent to simplify communication between medical institutions and the public and to ensure the greatest possible patient education and convenience. Innovations such as, for example, on-line consultation and improved web pages of hospitals and individual doctors' surgeries are appearing. E-mail communication between individual doctors and patients is now also operating as standard, with gynaecologists and paediatricians communicating with patients by e-mail most frequently. This can be explained by the fact that young women who consider this method of communication a matter of course communicate very often with doctors, in addition to the fact that this method provides the possibility of consultation on less serious issues without them having to visit the doctor's surgery at a specific time. Concerns on both sides about the possible violation of confidentiality arising from this communication and the resulting consequences represent a relatively significant barrier to the more rapid development of full doctor-patient communication.

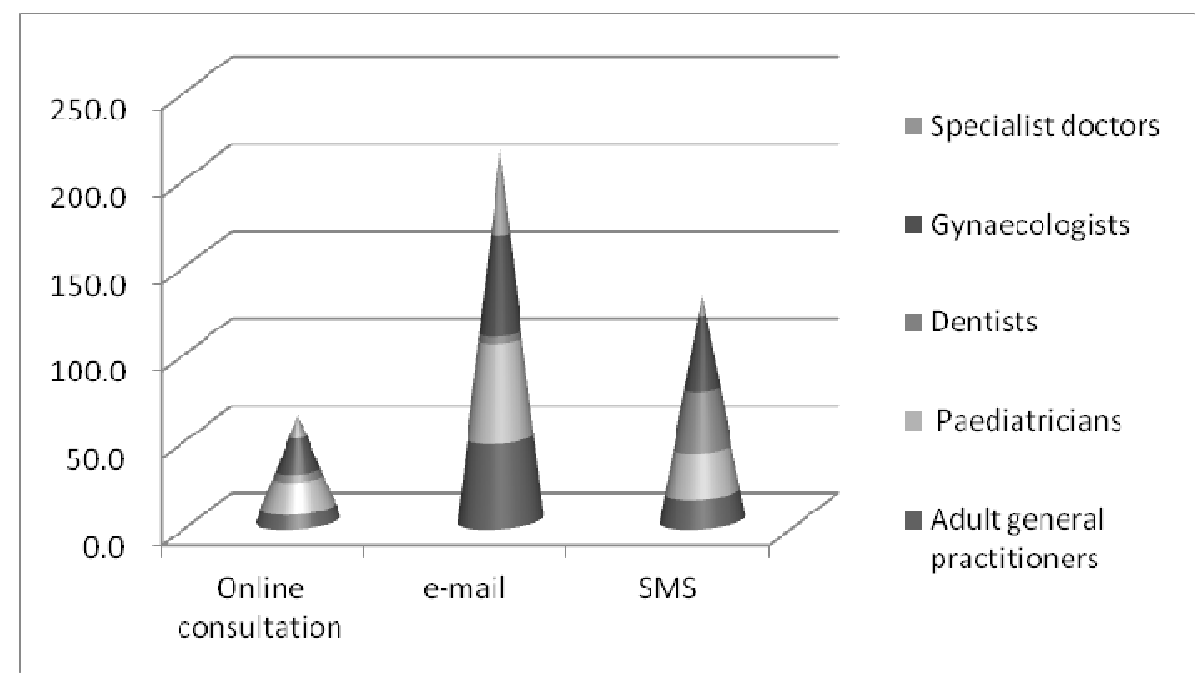

Figure 2: Certain way of e-communication with patients

\section{(Source: own questionnaire survey)}

We used cluster analysis to judge whether individual groups of doctors approach electronic communication in different ways.

\section{Cluster analysis}

Cluster analysis is an exploratory method used for further data processing (for example Budíková (2010), Plaček, Křápek, Puček (2014)). Cluster analysis is a method that investigates the similarity of multivariate objects (i.e. objects in which a larger number of characteristics is measured) and assigns them to classes or clusters. It is useful primarily when objects show a natural tendency to group together. In medicine, cluster analysis identifies illnesses and their various stages. In biology, cluster analysis is used in the classification of plants and animals. Three principal goals of a cluster analysis can be formulated: a description of systematics - the traditional use of cluster analysis for research goals and taxonomy (which is the empirical classification of objects), the simplification of data where cluster analysis provides a simplified view of objects when seeking a taxonomy, and finally identification of a relationship making it easier to uncover relationships between objects after clusters 
of objects, and thereby structures between objects, have been found.

The aim of cluster analysis is, then, the classification of $n$ objects (in this case groups of doctors), each of which is described by $p$ characteristics (in this case the percentage of doctors using a certain method of communication), into a number of (where possible) homogeneous groups (clusters). Objects within clusters must be as similar to each other as possible, while objects in different clusters must be as dissimilar as possible. The exact number of clusters is generally not known. The graphic output of a cluster analysis is called a dendrogram. The results of an agglomerative hierarchical procedure are generally depicted with a dendrogram [Řezanková 2010]. A dendrogram depicts the individual steps in the calculation of a cluster analysis.

Our data were divided into two parts for the purpose of cluster analysis. The first relates to information on communication between doctors and patients, the second information on communication between doctors and the outside world (colleagues, business partners, health insurance companies, etc.). In both cases that we analysed, groups of doctors are expressed on the vertical axis, while the horizontal axis depicts the distance (dissimilarity) between the individual clusters. A simple linkage is used as the rule of clustering and Euclidian distance as the metrics for the construction of a dendrogram.

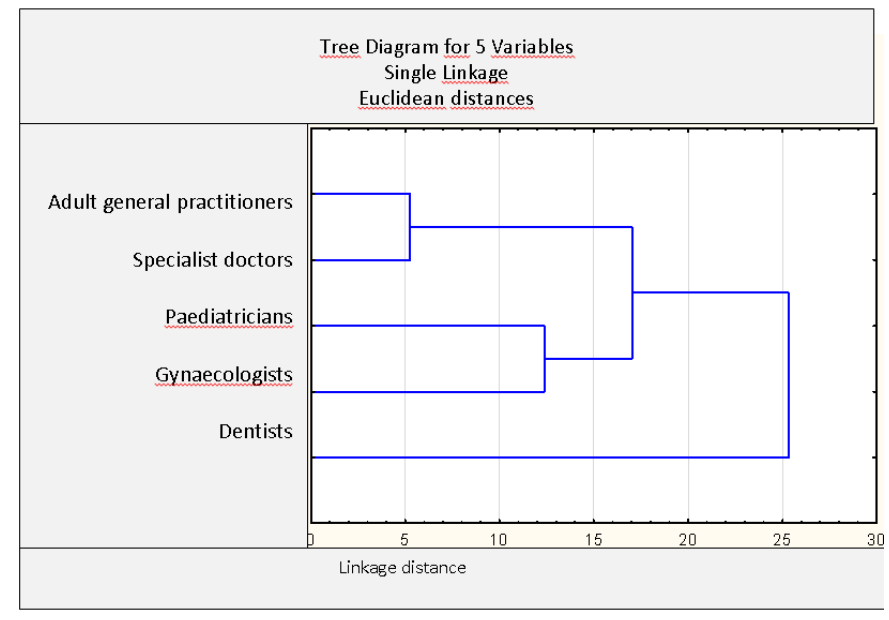

Figure 3: Communication between doctors and patients (Source: questionnaire survey, own calculation) 


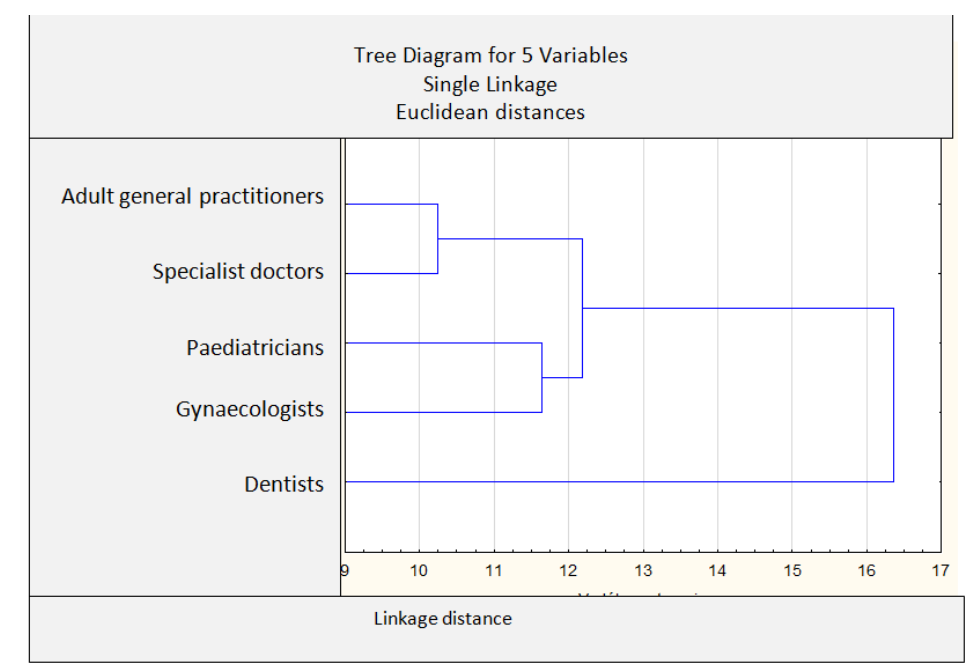

Figure 4: Communication between doctors and business partners

\section{(Source: own calculation)}

There are easily identifiable clusters on both resulting dendrograms that can help us identify which doctors have an approach to electronic communication different from others. We can clearly see from these dendrograms that general practitioners and specialist doctors behave in a similar manner in relation to electronic communication, with paediatricians and gynaecologists forming another "pair". Special incentives from health insurance companies, with the possibility of appointments being made with a general practitioner on line being rewarded with a significant bonus for the GP in question, for example, can be anticipated to play a large part in this. This bonus is also available to specialist doctors.

Dentists represent a separate group in both dendrograms. The different behaviour seen among

dentists can be explained by their specific specialisation. The need for dentists to communicate with the outside world is rather different to that of paediatricians, for example, as can be seen in Figure 2 which shows an extremely small level of interest in on-line consultation. Dentists also do not usually demand that laboratory results are received as soon as possible and do not have any great need for communication with pharmacies. As has already been mentioned, communication with patients takes place in a different way - remote communication takes place extremely rarely in view of the nature of the patients' problems. There is no great pressure for the modernisation of the system of making appointments in view of the fact that preventive checkups at the dentist are frequently neglected in the Czech Republic. Another reason is evidently the extremely broad clientele resulting in the large workload on dentists and the great quantity of administrative work that they are forced to prioritise.

\section{Conclusion}

There are many and various aspects to the work of a typical private doctor. In addition to the treatment of patients itself, he or she must also devote time to the operation of the surgery, assure the observation of legal regulations and perform the settlement of accounts with health insurance companies. e-Health represents a fundamental change to the work of the doctor. Administrative work is made easier, in spite of the fact that doctors work with an ever-increasing amount of information. Doctors can now obtain structured and undistorted information about the patient's medical 
history and the results of new tests ordered in a rapid and targeted manner.

Electronic communication between the doctor and the patient is a promising area of research in the application of information systems in healthcare. Sufficient use is not currently made of information technology for communication in healthcare, particularly by private dental surgeries. The process of making appointments and ensuring that patients wait no longer than an acceptable length of time for their appointments has also not been optimised.

The determination of optimal means and methods of communication between doctor and patient and between individual doctors is to comprise part of this research. A level of assurance of information security reducing the risk of any violation of the confidentiality of electronic communication to an acceptable level must be a necessary and significant criterion of optimality in addition to user simplicity. Only the introduction of a corresponding information security management system (ISMS) in accordance with ISO/IEC 27000 series standards in doctors' surgeries can assure the sustainability of the level of risk in accordance with Act 181/2014 Sb. A methodology for the introduction and operation of an ISMS in doctors' surgeries certificated by a certification agency in the area of information security in co-operation with top-level bodies in healthcare must be one of the outputs produced by the research.

Good initial conditions exist in the Czech Republic for the application of e-Health. Internet availability presents no problem and mobile Internet coverage is also good. There is still work to be done in ensuring that private doctors' surgeries are equipped with the necessary PCs, Internet, etc. Doctors are, however, evidently realising the necessity of owning a PC and using it in the performance of medical practice. The number of surgeries that own a PC though do not use it is insignificant. As the research conducted has shown, the potential exists for the ability to use information technology and information services to support a functional system of e-Health. The practical application of e-Health is not, however, possible without increasing the knowledge ability of e-Health among the medical professionals directly affected by this issue. The electronization of the Czech healthcare system is an extremely important step that will bring the Czech healthcare system closer to the standards seen in developed countries, while also representing an important tool for rapid and effective communication within Europe as a whole. The fact that the Czech Republic is one of the few countries in Europe, or indeed the world, to have a valid law on cybernetic security is a great advantage to the introduction of a functional and, most importantly, secure e-Health system in the Czech Republic.

\section{Acknowledgement}

This paper was supported by grant FP-S-162787 'Efektivní využití ICT a kvantitativních metod pro optimalizaci podnikových procesů' of the Internal Grant Agency at Brno University of Technology.

\section{References}

1. Ash, J.S. and Bates, D.W. (2005). Factors and forces affecting EHR system adoption: report of a 2004 ACMI discussion. Journal of the American Medical Informatics Association 12 , pp. 8-12

2. Berner, E.S., Detmer and D.E., Simborg, D., (2005). Will the wave finally break? A brief view of the adoption of electronic medical records in the United States. Journal of the American Medical Informatics Association 12,pp. 3-7

3. Budíková, M. ; Lerch, T. and Mikoláš, Š. (2006) Základní statistické metody. Brno : Masaryková univerzita, 45 s. ISBN 80-2103886-1.

4. Davidson, E.; Heslinga, D. (2006). Bridging the IT adoption gap for small physician practices: An action research study on electronic health records, Information Systems Management 24, pp. 1528

5. Douglas, T.J.; Ryman, J.A. (2003), Understanding competitive advantage in the general hospital industry: Evaluating strategic competencies. Strategic Management Journal 24, pp. 333-347 
6. European Commission, (2011), Elektronické zdravotnictví [Online], [downloaded at 2.9.2013]. Available: http://ec.europa.eu/healtheu/care_for_me/e-health/index_sk.htm

7. Ezdrav, (2013), Jak jsou využívány informační technologie v českém zdravotnictví? [Online], [downloaded at 2.9.2013]. Available::

http://www.ezdrav.cz/jak-jsou-vyuzivanyinformacni-technologie-v-ceskemzdravotnictvi/

8. Goldschmidt, P.G. (2005), HIT and MIS: Implications of health information technology and medical information systems. Communications of the ACM 48, pp. 69-74.

9. HealthCast, (2006), HEALTHCAST 2020: Creating a Sustainable Future. PricewaterhouseCoopers

10.Iakowidis, I., Wilson, P. and Healy, J.C. (2004), E-Health. Current Situation and Examples of Implemented and Beneficia eHealth Aplications. Amsterodam: IOS Press

11.Jha, A.K., Ferris, T.G., Donelan and al. (2006). How common are electronic health records in the United States? A summary of the evidence. Health Affairs 25, pp. 496-507

12.Karsh, B. (2004). Beyond usability: designing effective technology implementation systems to promote patient safety. Quality and Safety in Health Care 13, pp. 388-394.

13.Kawamoto, K., Houlihan, C.A., Balas, E.A., and Lobach, D.F. (2005). Improving clinical practice using clinical decision support systems: a systematic review of trials to identify features critical to success. British Medical Journa,l 330

14.Klein, R., (2007). An empirical examination of patient-physician portal acceptance. European Journal of Information Systems 16, pp. 751-761

15.Linder, J.A., Ma, J., Bates, D.W., Middleton, B., and Stafford, R.S. (2007). Electronic health record use and the quality of ambulatory care in the United States. Archives of Internal Medicine 167, pp. 14001405
16.Middleton, B., Hammond, W.E., Brennan, P.F., and Cooper, G.F. (2005). Accelerating U. S. EHR adoption: how to get there from here. Recommendations based on the 2004 ACMI retreat. Journal of the American Medical Informatics Association 12,pp. 13-19

17.Ohsfeldt, R.L., Ward, M.M., Schneider, J.E., Jaana, M., Miller, T.R., Lei, Y., et al., (2005). Implementation of hospital computerized physician order entry systems in a rural state: feasibility and financial impact. Journal of the American Medical Informatics Association 12, pp. 20-27

18.0verhage, J.M., Evans, L., and Marchibroda, J., (2005). Communities' readiness for health information exchange: the national landscape in 2004. Journal of the American Medical Informatics Association 12, pp. 107-112.

19.Plaček, M., Křápek, M., Puček, M., (20014). Využití kvantitativních metod pro analýzu veřejných rozpočtů na př́kladu výdajů obcí na opravy. In Ing. Pavel Jedlička, CSc.. Hradecké ekonomické dny 2014. 1. vyd. Hradec Králové: Univerzita Hradec Králové Fakulta informatiky a managementu, s. ISBN 978-80-7435-368-0.

20.Řezanková, H. ; Húsek, D. ; Snášel, V. (2009) Shluková analýza dat. Praha : Professional Publishing, 218 s. ISBN 978808-6946-818.

21.Singh, H.; Naik, A.D.; Rao, R.; Petersen, L.A., (2008). Reducing diagnostic errors through effective communication: Harnessing the power of information technology, Journal of General Internal Medicine 23, pp. 489-494.

22.Thompson, T.G. and Brailer, D.J., (2004). The decade of health information technology: delivering consumercentric and informationrich health care. Washington, D.C.: U.S. Department of Health \& Human Services.

23.Young, H.M., (2003). Challenges and solutions for care of frail older adults. Online journal of issues in nursing 8.

24.Zvára, K., Seidl, L., Zvárová, J., (2008): Projekt v kontextu aktuálního vývoje. Sborník Informační technologie pro rozvoj kontinuální sdílené péče o zdraví. Praha: EuroMISE

Veronika Novotná and Viktor Ondrák (2016), Journal of Eastern Europe Research in Business and Economics, DOI:10.5171/2016.398531 